Augsburger Rechtsstudien

87

Thomas M.J. Möllers/Hao Li (eds.)

The General Rules of

Chinese Civil Law

History, Reform and Perspective 
Augsburger Rechtsstudien

Herausgegeben im Auftrag der

Juristischen Fakultät der Universität Augsburg von

Professor Dr. Arnd Koch

Professor Dr. Thomas M.J. Möllers

Professor Dr. Matthias Rossi

Band 87 
Thomas M.J. Möllers/Hao Li (eds.)

The General Rules of Chinese Civil Law

History, Reform and Perspective 


\section{Principles in the Chinese Civil Code}

Thomas M.J. Möllers*

Abstract: The General Rules of Civil Law (GRCL) will have a substantial influence on the development of Civil Law in the Peoples Republic of China in the coming years. Similarly, the general legal principles embedded in the GRCL will help to shape and concretize this redefined legal code. It is in this way that fundamental principles such as the freedom of contract and the absolute protection of particular legal interests have finally been incorporated into the legal framework in China. The consideration and implementation of such principles belong to a category of particularly challenging aspects of juridical work. Such fundamental principles are often not codified and must therefore first be deducted via the interpretation of more complex legal ideas. Once this has been done, it is up to the lawyers under the consideration of the lex superior doctrine to further outline and concretise these principles in order to avoid and resolve possible collisions. The following article shows by means of numerous examples how in its early stage, Chinese Civil Law can be inspired by and learn from German legal dogma. At the same time, the following article comprises a detailed comparison of the fundamental principles found in the GRCL and the German Civil Code (BGB).

Keywords: Working with principles; legal principles; freedom to contract; legal idea; legal rule; legal doctrine; priority of norms; private autonomy; pacta sunt servanda; primacy of law.

Dr. iur. habil.; Professor, University of Augsburg, Faculty of Law. Managing Director of the Center for European Legal Studies, Chair for Civil Law, Economic Law, European Law, Private International Law and Comparative Law. The Contribution was presented during the conference of the research institute RICE, also at the China University of Political Science and Law, the Gansu College, and the Lanzhou University. I would like to thank the participants for the stimulating discussions during these events. 
I. On the legal relevance of legal principles

1. Excerpt of legal principles in the GRCL: voluntariness and freedom to contract, equality and protection of physical integrity and property

2. Terms and Distinctions $\quad 59$

a) Legal Principle (Rechtsprinzip) 59

b) Legal Concepts (Rechtsidee) 60

c) Legal Doctrine (Rechtsinstitute) 61

3. Legal Obligation and the Prevention of Empty Phrases 61

a) Obligation to Induct and Substantiate 61

b) Preventing empty phrases $\quad 62$

II. Derivation and substantiation of legal principles through the priority of norms (lex specialis)

1. Lex specialis - the more specific norm precedes, section 11 GRCL

2. Selected examples

a) The principle of voluntariness and substantiation through specific provisions

b) The protection of physical and proprietary rights and sections 107 et seqq. and sections 176 et seqq. GRCL

III. Substantiation through deduction of legal principles and the creation of new legal concepts

1. Induction and Deduction

2. Freedom to contract and binding effect of a contract

a) Freedom to contract according to sections 5,7 GRCL 67

b) Freedom of contract as a consequence of freedom of the will under German Law

c) The justification of a binding contract (pacta sunt servanda)

3. Private autonomy as self-determination for both parties

a) Self-determination of the individuals and mutual selfdetermination

b) Derivation of the principle of self-determination from the BGB and the constitution 
4. Deduction: The doctrinal legal justification of the various legal doctrines where the right of self-determination is absent

a) Obligation to contract and lack of self-determination

b) Price controls under section 138 para. 1 BGB for contracts which intervene in the self-determined life with severe freedom-restricting consequences

c) A freedom-restricting lack of equivalence as frustration of the contract

IV. Lex superior - Primacy of Law

1. The legal situation in Germany

a) The principle lex superior $\quad 76$

b) Higher rank of rules on competences $\quad 77$

c) Primacy of the Constitution $\quad 78$

2. The Primacy of Law in Chinese Law 78

a) The Primacy of Law according to Art. 95 Legislation Law 78

b) Chinese Law and the Constitution, section 1 GRCL 79

V. Resolution of conflicts between principles through balancing working with basic laws

1. No general principle of proportionality in the German BGB 80

a) Affirmation of a principle of proportionality in Civil Law

b) Rejection of the principle of proportionality in Civil Law

c) Own opinion

2. Principle of proportionality in Chinese Civil Law? 85

VI. Summary

\section{On the legal relevance of legal principles}

A lawyer does not only need to know and apply the law. A good lawyer knows the interplay between law, jurisdiction, and legal literature. Legal dogmatics is a combination of numerous written and unwritten rules which make the law understandable in the first place but which are indispensable for the profound understanding of the law. What are legal principles, though? How are the legal principles applied? The recently passed General Principles of Civil Law (GRCL) contain a shell thereof.

In the following, the legal principle will first be depicted and distinguished from the legal idea and the legal doctrine (I.). Then, four techniques 
to substantiate legal principles will be presented. The first one entails a reference to other more specific norms (II.). A second technique is the substantiation through induction and deduction (III.). Then, the methodology of the higher-ranking law will be described (IV.). Eventually, principles could be substantiated through balancing (V.).

In our society, having principles is usually a positive character trait for a person to have. If a person remains true to their principles, they are considered to be strong-willed, sincere, and straightforward. In this respect, politicians and representatives in election campaigns are very often prematurely assumed to put honest convictions aside in favour of securing power and influence; or acting opportunistically in the interests of the strongest lobby at the time, and against the interests of the sovereign people. According to Gandhi "politics without principles" even represents one of his famous seven deadly sins of modern society. ${ }^{1}$ It is therefore hardly a new insight that both our man-made Basic Law (GG) and the ordinary law are permeated with numerous principles which are meant to ensure that the law is as straightforward as possible. However, it is all the more astonishing that only a few of these legal principles are set out in positive law. So, for example, there is as little explicitly recorded in writing on the principle in the law of obligations of freedom of contract ${ }^{2}$ in the German Civil Code (BGB) as there is on the principle of contractual fidelity (pacta sunt servanda) ${ }^{3}$. However, no one seriously disputes the existence and applicability of these principles. Other states, however, have codified numerous principles. ${ }^{4}$

1 Mahatma Gandhi, Seven Social Sins, 43 Young India October 22, 361 (1925): "politics without principles".

2 The term is even referred to in the Motive zu dem Entwurfe eines Bürgerlichen Gesetzbuches für das Deutsche Reich (Statements on the Draft of a Civil Code for the German Reich), vol. 2, 2 (1896): "By virtue of the principle of freedom of contract, which governs the law of contractual obligations, the parties can determine their legal relationships and associations between themselves at their discretion with binding effect, insofar as there are no conflicting general or specific individual absolute legal provisions".

3 In contrast, the principle was even found in the original Article 77 of the Entwürfe eines Bürgerlichen Gesetzbuches für das Deutsche Reich (Draft of a Civil Code for the German Reich) (1888): "In order to conclude a contract, it is necessary for the contracting parties to declare their corresponding intentions to each other"; This Article 77 was then deleted by the second commission, see Commission's Report, 156, Benno Mugdan, Die gesamten Materialien des Bürgerlichen Gesetzbuchs für das Deutsche Reich, vol. 1, 688 (1899).

4 On pacta sunt servanda see for example fn. 28; on immorality see fn. 47. 
1. Excerpt of legal principles in the GRCL: voluntariness and freedom to contract, equality and protection of physical integrity and property

Three principles of the GRCL have been chosen to provide an example of how to work out a structure with principles: In section 5 GRCL, the principle of the freedom to contract is phrased as the "principle of voluntariness". Hereto Professor Wei Shen stated in his contribution to the conference: "As the principle of voluntariness is rooted in the Western enlightenment conception of the individual, it is ironic that Chinese law should embrace a break with values rooted in Chinese family and collective traditions and it is similarly a milestone in the break with socialist values restricting freedom of economic action."

In Chinese law, one principle that is particularly stressed is the equality of the parties. It can be found in section 2 as well as in section 4 GRCL. In German law, equality is located in Art. $3 \mathrm{GG}$ and as such is primarily a basic law and a right of defence against the state. Section 5 of the GPCL of 1986 still stated that "civil rights and interests of the citizens and legal entities" must be protected. The present section $3 \mathrm{GRCL}$ phrases with more intensity that physical rights and property rights [...] may not be infringed by individuals or organisations.

\section{Terms and Distinctions}

\section{a) Legal Principle (Rechtsprinzip)}

A definition of a legal principle must contain three components: Legal principles or (often used synonymously) principles of law are initially only partly standardised, and often not set out in law at all. They are extracted from the legal system as the totality of the written and unwritten legal norms and are more than legal concepts. They allow a certain generalisation. ${ }^{5}$ Principles form "the deep structure of the law". 6

5 Jürgen Basedow, 200 AcP 446, 453 (2000). In detail, also Claus-Wilhelm Canaris, Die Feststellung von Lücken im Gesetz, 47 et seq ( $2^{\text {nd }}$ ed. 1983).

6 Klaus Friedrich Röhl and Hans Christian Röhl, Allgemeine Rechtslehre, 283 ( $3^{\text {rd }}$ ed. 2008). 
They generally claim normative validity and lead to a presumption of conformity. ${ }^{7}$ However, principles are frequently not classifiable and require further specification through legal rules or balancing. Or in the words of Bydlinski: "They are thus guiding principles and grounds of justification of a legal provision, but not the positive provision itself." 8 The Basic Law already contains those which are probably the best known: Fundamental rights are principles par excellence. The mere fact that legal principles dominate our highest-ranking codifications shows their enormous importance in reaching legally sound decisions, and thus forces legal scholars to discuss them.

\section{b) Legal Concepts (Rechtsidee)}

Legal concepts have a higher status than legal principles. They provide reasons for norms which formulate the requirements or prohibitions. ${ }^{9}$ Such legal concepts, which are to some extent also referred to as values ${ }^{10}$, are of a higher level of abstraction and frequently too general for them to be used to resolve a case. Legal concepts such as justice, expediency and legal certainty must therefore also be further specified to make it possible to have transparent, persuasive trains of thought and justification. Otherwise there is a risk that the concept is only used as an empty phrase. ${ }^{11}$

$7 \quad$ Klaus Friedrich Röhl and Hans Christian Röhl, Allgemeine Rechtslehre, 284 ( $3^{\text {rd }}$ ed. 2008).

8 Franz Bydlinski, Juristische Methodenlehre und Rechtsbegriff, $132\left(2^{\text {nd }}\right.$ ed. 1991).

9 Matthias Mahlmann, Rechtsphilosophie und Rechtstheorie, section 24, § 13 ( $3^{\text {rd }}$ ed. 2015).

10 Wolfgang Fikentscher, Methoden des Rechts, vol. 4, 394 et seq. (1977).

11 This particularly applies for the concept of the "nature of the matter". See Heinrich Dernburg, Pandekten, vol. 1, 84 (7. ed. 1902); Heinrich Dernburg, System des römischen Rechts, vol. 1, section 32.2, 64 ( $8^{\text {th }}$ ed. 1911); Andreas von Thur, Allgemeiner Teil des Bürgerliches Rechts, vol. 1, 42 (1910); Arthur Kaufmann, Analogie und „Natur der Sache“ ( $2^{\text {nd }}$ ed. 1982); Friedrich Müller, Normstruktur und Normativität, 94 et seq. (1966); Karl Larenz, Methodenlehre der Rechtswissenschaft, 417 et seqq. ( $6^{\text {th }}$ ed. 1991) with further citations; Claus-Wilhelm Canaris, Die Feststellung von Lücken im Gesetz, $100\left(2^{\text {nd }} e d .1983\right)$. 
c) Legal Doctrine (Rechtsinstitute)

Legal principles require further specification to be applicable for the specific case. A legal rule can exist in a legal doctrine developed by jurisprudence, such as the obligation to contract. A legal doctrine, in its application, is then eventually a rule in the sense of Alexy or a positive rule in the sense of Bydlinski. ${ }^{12}$ In the interim, it is substantiated and, through the development of tangible, directly classifiable features, has also acquired a binding character ${ }^{13}$ and apparent authority. ${ }^{14}$

\section{Legal Obligation and the Prevention of Empty Phrases}

a) Obligation to Induct and Substantiate

Some claim that legal principles are mere declarations of intent without legal relevance ${ }^{15}$. In the following, the opposite view is held. Legal principles, such as pacta sunt servanda, are legally significant. This is in accordance with the law in Germany. It is generally assumed that the BGB presupposes these principles as simply being obviously valid. ${ }^{16}$ However, they need to be legally defined. Then, it needs to be outlined how they are applied. They need to be deducted in a first step and then substantiated in a second step.

12 See also Thomas M.J. Möllers, Juristische Methodenlehre, § 11 recital 12 et seqq. (2017).

13 Thus, for example, liability for apparent rights is established as a legal principle from sections 171, $172 \mathrm{BGB}$ and section $405 \mathrm{BGB}$. This principle is then developed into the legal doctrine of agency by estoppel, Bundesgerichtshof [BGH] [Federal Supreme Court], October 15, 1987, III ZR 235/86, BGHZ 102, 60, 64; then without the doctrinal derivation: BGH, May 11, 2011, VIII ZR 289/09, BGHZ $189,346 \S 15$ - use of a third-party eBay member's account.

14 BGH, January 20, 1983, VII ZR 32/82, BGHZ 86, 273, 274 et seq. - apparent authority.

15 William C Jones, 28 Harv. Int'l. L.J. 309 (1987).

16 Thus Werner Flume, DJT 135, 136 et seq. (1960); Werner Flume, Allgemeiner Teil des Bürgerlichen Rechts, Das Rechtsgeschäft, vol. 2, section 1.1, 1 (1965); agreeing Claus-Wilhelm Canaris, 200 AcP 273, 277 (2000); Reinhard Bork, Allgemeiner Teil des Bürgerlichen Gesetzbuchs, recital 99 (4 ${ }^{\text {th }}$ ed. 2016). 
b) Preventing empty phrases

Section 6 GRCL uses the principle of "fairness" to determine rights and obligations of the parties. Section 7 GRCL mentions the principle of good faith. It was originally codified in section 4 GPCL and followed the German "good faith" of section 242 BGB. In Chinese law applying the principle of good faith is treated with respect because its vagueness is criticised. For this reason, it is not sufficient to use empty phrases. In the German law legal principles are in part derived from the "nature of the matter" (Natur der Sache). This was first introduced by Dernburg ${ }^{17}$ and later accepted by the literature ${ }^{18}$ and jurisdiction ${ }^{19}$. This is rejected because the term "nature of the matter" does not establish anything by itself. ${ }^{20}$ Also legal ethical principles as for example "justice" and "fairness" need to be further substantiated to make comprehensible, persuasive thoughts and justifications possible.

\section{Derivation and substantiation of legal principles through the priority of} norms (lex specialis)

1. Lex specialis - the more specific norm precedes, section 11 GRCL

Section 11 GRCL determines that specific provisions precede. ${ }^{21}$ The German law is also very aware of this principle. The rule lex specialis derogat

17 Heinrich Dernburg, Pandekten, vol. 1, 87 (4th ed. 1894); Heinrich Dernburg, System des römischen Rechts, vol. 1, 64 ( $8^{\text {th }}$ ed. 1911); Andreas von Thur, Allgemeiner Teil des Bürgerliches Rechts, vol. 1, 42 (1910).

18 In detail Karl Larenz, Methodenlehre der Rechtswissenschaft 417 et seqq. (6 ${ }^{\text {th }}$ ed. 1991); Claus-Wilhelm Canaris, Die Feststellung von Lücken im Gesetz 100 ( $2^{\text {nd }}$ ed. 1983).

19 BVerfG, February 20, 1952 (Az. 1 BvF 2/51), BVerfGE 1, 117, 131.

20 Critical: Horst Dreier, Zum Begriff der „Natur der Sache“, 127 et seq. (1965); Klaus Friedrich Röhl and Hans Christian Röhl, Allgemeine Rechtslehre, 74 ( $3^{\text {rd }}$ ed. 2008): "It turns out that the issue of the essence as well as the nature of the matter does not add any argument at any point"; Peter Raisch, Juristische Methoden, 178 (1995); Bernd Rüthers, Christian Fischer and Axel Birk, Rechtstheorie, recital 929 ( $9^{\text {th }}$ ed. 2016).

21 See also Yuanshi Bu, ZChinR 183, 186 et seq. (2017). 
legi generali is based on Roman law $^{22}$ and means that a specific law precedes the general law. The same rule can be found in Anglo American law: Generalia specialibus non derogant: A general rule cannot supersede a more specific rule..$^{23}$ The principle of lex specialis must be affirmed if a claim depends on requirements that are more restrictive and unfavourable. ${ }^{24}$

\section{Selected examples}

a) The principle of voluntariness and substantiation through specific provisions

The principle of voluntariness is derived from section 5 GRCL. It is substantiated in Chinese law. The principle of good faith according to section 7 GRCL is substantiated by section 119 GRCL insofar that a contract is legally binding and thus must be adhered to. In European law the principle of "pacta sunt servanda" is well-known. The counterpart to freedom of contract is the binding contract or contractual fidelity (pacta sunt servanda). The principle of a binding contract is not of Roman origin, ${ }^{25}$ but was rather first developed for all types of contract by canon law, the late scholasticism,

22 For the original in Greek, see Mod. D. 1,4,4 as well as Pap. D. 48,19,41: nec ambigitur in cetero omni iure speciem generi derogare; see also Sebastiano Medici, De legibus, statutis, et consuetudine, 92 (Sebastiano Medici et al. eds., 1574): Lex specialis derogat generali.

23 Or literally: General provisions do not precede specific provisions; Oliver Jones and Francis Alan Roscoe Bennion, Bennion on Statutory Interpretation 281 (6 $6^{\text {th }}$ ed. 2013).

24 Ernst A. Kramer, Juristische Methodenlehre, $119\left(5^{\text {th }}\right.$ ed. 2016) with reference to Hans Merz, Festschrift for Guhl, 87, 94 et seqq. (1950); note also Thomas M.J. Möllers, Juristische Methodenlehre, $\S 4$ recital 134 (2017).

25 Roman law did not have any general option to be able to sue for contractual obligations. See in detail, Gerhard Kegel, Vertrag und Delikt, 3 et seq. (2002). 
and the natural $\mathrm{law}^{26}$ and German sources of $\mathrm{law}^{27}$. One can find the principle expressly in the Motive,${ }^{28}$ but not in the BGB, because the rule that the concurrence of wills is contractually binding was assumed to be known by the Second Commission and therefore deleted.

However, the principle of a binding contract has to be limited. This is why a civil law transaction is voidable if it has come into existence on the basis of a threat or deceit, sections 148-150 GRCL. Also in German law there is contractual justice by procedural fairness. Threat or bad faith do not automatically result in voidness but allow the contestation of the contract according to sections $119,123,142$ BGB.

b) The protection of physical and proprietary rights and sections 107 et seqq. and sections 176 et seqq. GRCL

The protection of physical and proprietary rights as a general principle in section 3 GRCL is substantiated by numerous particular provisions: In sections 107 et seqq. GRCL there are numerous provisions which reinforce legally protected rights. The GRCL are not restricted to the legally protected rights of life, body, health and freedom in section 823 para. $1 \mathrm{BGB}$, but also explicitly protect human dignity, the right to privacy or data security, section 109 et seqq. GRCL. Here, the Chinese law is, without doubt, more modern than the version of the BGB from 1900. Up to the present day, the German legislator, for example, has failed to codify the general right of privacy despite several initiatives. ${ }^{29}$

26 See Christian Freiherr von Wolff, Grundsätze des Natur- und Völkerrechts, section 438 (1754): "When two or more jointly agree on one or more promises, it is a contract (pactum or pactio)." See Klaus-Peter Nanz, Die Entstehung des allgemeinen Vertragsbegriffs im 16.-18. Jahrhundert, 149 et seq. (1985); Helmut Coing, Europäisches Privatrecht, vol. 1, 397 et seq. (1985); in detail, Gerhard Kegel, Vertrag und Delikt, 3 et seq. (2002).

27 Sachsenspiegel, Leipziger Ausgabe, $1^{\text {st }}$ book, Art. 7 (1595): "That which a man promises, so should he keep"; Glück, Ausführliche Erläuterungen der Pandekten, nach Hellfeld - ein Kommentar für meine Zuhörer, vol. 4, 279 et seq. (1786), with reference to the German legal rule: "A man's word is his bond." See also Friedrich Carl von Savigny, System des heutigen Römischen Rechts, vol. 3, 309 (1840).

28 Entwurf eines Bürgerlichen Gesetzbuches für das Deutsche Reich, section 77 (1888).

29 Thomas M.J. Möllers, Juristische Methodenlehre, § 7 recital 72 et seqq. (2017). 
The legal consequence in section 120 GRCL is tort liability which in return is substantiated in sections 176 et seqq. GRCL: Not only the restitution of the original state but also the contractual penalty and alternative penalties can be comprised if it is stipulated by a law, section 179 GRCL. Such legal provisions exist as Wei Shen stated in his contribution to the conference: "Punitive damage, as the civil responsibility liability form of preventing and punishing the larger vicious violations through economic means, has been explicitly adopted by China's multiple single-line legislation. For example, Article 47 (Product Liability) of the Tort Liability Act, Article 55 (Consumers Fraud) of the Consumer Protection Act, and Article 148 (Food Safety Responsibility) of the Food Safety Law. The "General Principles of Civil Law" will formally put the punitive damages into one of the civil responsibility liability forms, which will likely lead to punitive damages being used more in future single-line legislation." The introduction of the punitive damages adds a deterrent effect to the claim for damages and thus renders them efficiently: It remains to be seen how rights as "human dignity" and "privacy" have to be interpreted, sections 109 et seq. GRCL. Foreign companies such as Apple, Google or Facebook and Chinese companies such as Alibaba, Tencent, and Baidu use their customers' personal data on a large scale. It is till unknown if the extensive basis of liability will lead to a liability risk that is difficult to gauge. Under a legal comparison, two further particularities should be pointed out: If the human dignity is worth protecting, a violation or exposure is quickly reached. In German law, this basic law is treated with special care. ${ }^{30}$ The general right of privacy is called a "framework law"31 and it is differentiated between social, private and intimate sphere. Moreover, a balancing with the other party's interests takes place. $^{32}$

30 Prevailing view, BVerfG, June 3, 1987, 1 BvR 313/85, BVerfGE 75, 369, 380: "absolutely without a possibility to weigh up the choices (Güterabwägung)"; BVerfG, October 10, 1995, 1 BvR 1476/91 among others, BVerfGE 93, 266, 293: "the human dignity as the root of all basic rights is not open to balancing with any other individual basic right"; Michael Sachs and Wolfram Höfling, GG, $\S 1$ Rn. 11 ( $7^{\text {th }}$ ed. 2014); Jochen von Bernstorff, JZ 905 et seqq. (2013); Horst Dreier, GG (Horst Dreier ed., $3^{\text {rd }}$ ed. 2013), Art. 1 I recital 46 with further references differing view Manfred Baldus, AöR 136, 529 et seqq. (2011).

31 Prevailing view among others Wolfgang Fikentscher and Andreas Heinemann, Schuldrecht, recital $1582,1584\left(10^{\text {th }}\right.$ ed. 2006).

32 See below V.1.c). 
III. Substantiation through deduction of legal principles and the creation of new legal concepts

\section{Induction and Deduction}

Legal principles serve the development of law with already existing valuations. Figuratively speaking, legal principles link the existing law and the law that has yet to be developed. The combination of induction and deduction serves this purpose $\mathrm{e}^{33}$. The literature of the deduction of legal principles also favours Induction which is the conclusion from the specific to the general. ${ }^{34}$ According to Canaris the derivation of a thought comes from several legal provisions. ${ }^{35}$ Deduction is the conclusion from the general to the specific. In the underlying context it describes how a general legal principle operates in the solution of a specific legal problem, which is from the principle to the rule. As well as the derivation of a general legal principle through induction is judicial development of the law, the legal rules and concepts obtained by deduction from the legal principles are development of the law.

Further substantiation is possible forming categories, subprinciples and similar factual conditions. The same procedure is applied to general stipulations trying to substantiate them with subprinciples, categories and similar factual conditions. Now, primarily pure case law is substantiated without such a legal basis.

Eventually, there is one last step to obtain a new legal sentence, e.g. a new basis for a claim, from a legal principle through development of the law. This is often accompanied by great uncertainty about how to justify them with legal dogmatics. A prime example in German law for this is the

33 More detailed Thomas M.J. Möllers, Juristische Methodenlehre, $\S 11$ recital 19 et seqq. (2017).

34 In detail Aristoteles, Aristoteles' Erste Analytiken or: Lehre vom Schluss, chapter 23, 142 (Kirchmann ed. 1877); Francis Bacon, Novum Organum, Book I, Aphorismus CIV, 82 (1620).

35 For example Claus-Wilhelm Canaris, Die Feststellung von Lücken im Gesetz, 100,97 et seq. ( $2^{\text {nd }}$ ed. 1983 ): "A common legal thought is derived from several legal provisions and it is awarded the quality of a general legal one"; Neil MacCormick, Legal Reasoning and Legal Theory, 153 et seq., 232 et seq. (1978). 
obligation to contract ${ }^{36}$, the frustration of contract $^{37}$, and the contracts with protective effect to the benefit of third parties. ${ }^{38}$ The jurisdiction has substantiated the newly developed legal rules by categories and similar factual conditions. As inherent to the judicial development, the approaches are experimental and the practical application can sometimes only be developed through a trial and error process.

\section{Freedom to contract and binding effect of a contract}

a) Freedom to contract according to sections 5, $7 \mathrm{GRCL}$

The freedom to contract is codified in section 5 GRCL with the wording that the civil legal relationship can be introduced, changed and terminated according to the will of the individual. The new GRCL substantiated the obligations to adhere to promises of section $7 \mathrm{GRCL}$ insofar that a contract is legally binding, section 119 GRCL. This principle is known in German law as "pacta sunt servanda".

b) Freedom of contract as a consequence of freedom of the will under German Law

Private autonomy includes freedom of contract, but also freedom of ownership (section 903 BGB), freedom to marry (section 1297 BGB) and testamentary freedom, so the right to freely dispose of one's assets in the event

36 Reasoning on the basis of section 826 BGB RG, November 7, 1931, V 106/31, RGZ 133, 388, 392 - theater critic or for example BGH, December 2, 1974, II ZR $78 / 72$, BGHZ $63,282,285$ - compulsory admission to a monopoly organization. See for the newer view that derives an obligation to contract from a quasinegatory injunctive relief Karsten Schmidt, DRiZ 97, 98 (1977); Reinhard Bork, Julius von Staudingers Kommentar zum BGB, preliminary note on sections 145 et seqq. recital 2 (ed. 2015); Jan Busche, Münchener Kommentar BGB, before section 145 recital 21 ( $6^{\text {th }}$ ed. 2012); Christian Armbrüster, BGB, before section 145 recital 29 (Walter Erman ed., 14 ${ }^{\text {th }}$ ed. 2014).

37 See for example BGH, February 25, 1993, VII 24/92, BGHZ 121, 378 recital 48.

38 Before RG, February 10, 1930, VI 270/29, RGZ 127, 218, 221 - Gas meter. 
of death (section 1937 BGB) ${ }^{39}$ Freedom of contract in turn includes freedom to conclude contracts, freedom of contractual partner, freedom of content, and generally freedom of form, but also freedom to amend and cancel. ${ }^{40}$ The concept of freedom of contract was first introduced in the mid$19^{\text {th }}$ century. ${ }^{41}$ Freedom of contract is based on the intentions of the parties. ${ }^{42}$ The parties can determine their legal relationships between themselves at their discretion, insofar as there are no conflicting legal provisions.

The parties are generally responsible for agreeing to the essentialia negotii, the essential components of the contract, such as the object of purchase and the purchase price. The price is not controlled. The parties may also conclude unreasonable contracts. ${ }^{43}$ That corresponds with the liberal approach of Adam Smith, who described the market as the "invisible hand", on which supply and demand regulate themselves. ${ }^{44}$ The underlying idea is that the conflict of interests between the parties lead to a correct result through the contract; one could refer to the "guaranteed correctness" of the negotiation. ${ }^{45}$ Hobbes accurately stressed that it is the parties who are best

39 Motive zu dem Entwurfe eines Bürgerliches Gesetzbuches für das deutsche Reich, vol. 2, 2 ( $2^{\text {nd }}$ ed. 1896).

40 Reinhard Bork, Allgemeiner Teil des Bürgerlichen Gesetzbuchs, section 661 ( $4^{\text {th }}$ ed. 2016); Manfred Wolf and Jörg Neuner, Allgemeiner Teil des Bürgerlichen Rechts, section $10, \S 33$ et seq. ( $11^{\text {th }}$ ed. 2016); Thomas M.J. Möllers, JuS 1191, 1192 (1999).

41 Friedrich Carl von Savigny, Das Recht des Obligationenrechts, vol. 2, sections 72-78 (1853); Bernhard Windscheid, Lehrbuch des Pandektenrechts, vol. 2, section 312 , fn. 5 with further citations ( $8^{\text {th }}$ ed. 1900); see Werner Scherrer, Die geschichtliche Entwicklung des Prinzips der Vertragsfreiheit, 33 et seq. (1948); Joachim Rückert, Naturrecht und Rechtsphilosophie in der Neuzeit, 135, 145 et seq. (Diethelm Klippel ed., 1997).

42 Motive zu dem Entwurfe eines Bürgerliches Gesetzbuches für das deutsche Reich, vol. 2, 126 ( $2^{\text {nd }}$ ed. 1896): "Legal transaction in the sense of the Draft is a personal declaration of intent, aimed at emphasising a legal outcome, which occurs under the legal system as a result, because it is intended."

43 Oberlandesgericht [OLG] [Higher Regional Court] of Cologne, December 8, 2006, 19 U 109/06, MMR 2007, 446, 448: Purchase of a sugar beet harvester worth 60,000 euros in an eBay auction for 51 euros; agreeing, Marc-Philippe Weller, Die Vertragstreue, 170 (2009).

44 Adam Smith, Wealth of Nations, vol. III, book IV, chap. II ( $9^{\text {th }}$ ed. 1799), Of Restraints upon the Importation from foreign Countries of such Goods as can be produced at Home, p. 181.

45 Walter Schmidt-Rimpler, 147 ACP 130, 149 et seq. (1941); Walter SchmidtRimpler, Festschrift for Raiser 3, 5 et seq. (1974); Manfred Lieb, 178 AcP 196, 206 (1978). 
able to determine the value of the item. ${ }^{46}$ This concept has been taken up by the BGB. For example, in addition to the conspicuous disparity between benefit and consideration as a further prerequisite to establish usury, section 138 para. 2 BGB requires that freedom of choice is impaired, such as with the exploitation of plight. This corresponds with the legal position in numerous other legal systems. ${ }^{47}$ Thus only procedural fairness was to be ensured, guaranteed process, by protection against mistake or fraud (sections 119,123 et seq., 142 et seq. BGB). ${ }^{48}$

\section{c) The justification of a binding contract (pacta sunt servanda)}

As the principle of a binding contract (pacta sunt servanda) cannot be taken directly from the law, one must derive it from the law indirectly by induction: Thus a person who offers to conclude a contract with another person is "bound by the offer" section 145 BGB. The contract and the contractual obligation follow from the deliberate statement to accept an offer. Without consensus, this leads to disagreement under sections 154 et seq. BGB. The mistake - the conflict of intention and declaration - is initially irrelevant for the binding effect. The contract is valid despite the mistake and only permits a challenge under sections 119,142 BGB. ${ }^{49}$ The binding contract can be discerned from the synallagmatic fulfilment obligations of the individual types of contract $^{50}$ or the general fulfilment obligations at the time of performance (section $271 \mathrm{BGB}$ ), the right of retention (section $273 \mathrm{BGB}$ ), and impossibility (section 275 BGB). Moreover, good faith (section 242 BGB) can be used to justify the obligation for contractual fidelity. ${ }^{51}$ Moreover, under the 2001 reform of the law of obligations, freedom of contract and

46 Vividly, Thomas Hobbes, Leviathan, part I, chap. 15, 74 ( $2^{\text {nd }}$ ed. 1886): "The value of all things contracted for, is measured by the appetite of the contractors: and therefore the just value is that which they be contented to give."

47 Art. 21 OR (Swiss Code of Obligations); Art. 282 port. cc (Portuguese código civil); Art. 388 Polish Civil Code of 23/04/1964.

48 On this procedural concept of fairness, see Konrad Zweigert and Hein Kötz, Einführung in die Rechtsvergleichung, 320 et seq. ( $3^{\text {rd }}$ ed. 1996).

49 Sibylle Hofer, HKK-BGB, with section 145, § 10 (2003).

50 Such as from the contract of sale (section 433), rental agreement (section 535), contract for work (section 633) or contract for services (section 631 BGB).

51 BGH, December 17, 1982, V ZR 306/81, BGHZ 86, 167, 171 - increase in a ground rent in the absence of a contractual adjustment clause. 
the binding contract can be established by sections 241,311 para. 1 BGB..$^{52}$ The binding contract can be derived from the provisions cited by induction.

\section{Private autonomy as self-determination for both parties}

a) Self-determination of the individuals and mutual self-determination

With the presentation of the legal doctrine above, too much consideration was given to freedom of contract, and conversely self-determination was neglected. Self-determination is a prerequisite for the freedom of contract. The following wording is already contained in the Motiven zum BGB: "The legal system cannot allow free self-determination to be impaired in legal transactions in an unlawful way." 53 And the first sentence in Flume's work "Rechtsgeschäft" reads: "Private autonomy is the name given to the principle of self-organisation of legal relationships by the individual according to his/her will." ${ }^{54} \mathrm{He}$ continued verbatim: "For as far as self-determination reaches, there is no external control. The deliberate decision is valid because it is intended and the will of the individual is respected as such. Private autonomous organisation requires, insofar as it is recognised by law, no justification other than that the individual intends it." $" 55$

Self-determination is often only referred to in relation to one party. ${ }^{56}$ However, the principle of self-determination obviously applies for both

52 Andreas Their, HKK-BGB, section 311 I, $\$ 1$ (2007); Marc-Philippe Weller, Die Vertragstreue, 170 (2009).

53 Motive zu dem Entwurfe eines Bürgerlichen Gesetzbuches für das Deutsche Reich (Statements on the Draft of a Civil Code for the German Reich), vol. 1, 204 (1888); in German it says: „Die Rechtsordnung kann nicht gestatten, daß die freie Selbstbestimmung auf rechtsgeschäftlichem Gebiete in wiederrechtlicher Weise beeinträchtigt wird."

54 Werner Flume, Allgemeiner Teil des Bürgerlichen Rechts, vol. 2, 1 (4 ed. 1992); as above Werner Flume, Festschrift 100 Jahre DJT, vol. 1, 135, 136 et seq., 143 (1960); agreeing Claus-Wilhelm Canaris, 200 AcP, 273, 277 (2000); Reinhard Bork, Allgemeiner Teil des Bürgerlichen Gesetzbuchs, $\S 99$ (4 $4^{\text {th }}$ ed. 2016); Joachim Rückert, HKK-BGB, with section 1 § 108 (2003) speaks of "drumbeat." See also BVerfG, May 13, 1986, 1 BvR 1542/84, BVerfGE 72, 155, 170.

55 Werner Flume, Festschrift 100 Jahre DJT, vol. 1, 135, 141 (1960).

56 Jan Busche, Münchener Kommentar BGB, section 145 Paragraph 6 and the evidence in section $12 \mathrm{fn} .65$ ( $7^{\text {th }}$ ed. 2015); Manfred Wolf and Jörg Neuner, Allgemeiner Teil des Bürgerlichen Rechts, section $10, \S 30$ (11 $1^{\text {th }}$ ed. 2016). 
sides. Self-determination of both sides then also means protection against external control. ${ }^{57}$ Flume rightly emphasises that the contract requires mutual self-determination and that an inequality of power or factual monopoly position leads to one-sided external control. The concept of mutual selfdetermination as part of private autonomy was met with approval. ${ }^{58}$ Flume had already formulated the following in 1960 :

"Insofar as individuals are provided the right to regulate legal relationships by mutual self-determination, that is by contract, in our legal system, it is based on the requirement that the individuals face one another with the power of self-determination, and do not enter into contracts by the power of one-sided external control instead of mutual self-determination. Compulsion and private autonomy are incompatible with one another. However, it is private autonomy's eternal dilemma that it is continually brought into question by an unequal distribution of power." 59

b) Derivation of the principle of self-determination from the BGB and the constitution

One can now discern this principle from an indirect third-party effect of the fundamental rights. In the decision on the guarantee of relatives without assets, the BVerfG stressed that Art. 2 para. 1 GG guarantees the "self-determination of the individual in legal life" 60 as part of private autonomy. It also required such an understanding of private autonomy in several decisions, where there would have been a "structural inequality of bargaining

$57 \quad$ Norbert Reich, JZ 609 (1997).

58 Franz Jürgen Säcker, Münchener Kommentar BGB, Introduction Paragraph 37 ( $7^{\text {th }}$ ed. 2015).

59 Werner Flume, Festschrift 100 Jahre DJT, vol. 1, 135, 143 (1960); similarly Karl Larenz, Schuldrecht, vol. 1, section 4, 41 (14. ed. 1987): "free self-determination of each of the two contracting parties".

60 BVerfG, October 19, 1993, 1 BvR 567 inter alia, BVerfGE 89, 214, 231 - guarantee agreements referring to Hans-Uwe Erichsen, HdB Staatsrecht, vol. 6, section 152 paragraph 58 et seq. (Hans-Uwe Erichsen ed. 1989), which in fn. 195, 197, again refers to Werner Flume (fn. 59). 
power" or a "disrupted contractual parity". ${ }^{61}$ In terms of a constitution-oriented (reinforcing) interpretation, there is nothing to preclude this. ${ }^{62}$

However, it is more convincing to interpret the principle of self-determination as part of the private autonomy of both parties and thus as a civil law legal principle. This principle can be found in the BGB in the intention theory of the $19^{\text {th }}$ century, then standardised in section 133 ("to ascertain the true intention"), and the error rules (section 119 et seq.). Self-determination is also guaranteed in family and probate law. ${ }^{63}$ Seen historically, the BGB did not only want to introduce freedom, but also an equal legal freedom ${ }^{64}$ without differentiation between persons. Through European law the cancellation (section 312 BGB) was also added, which strengthened the self-determination of the consumer. Equal legal freedom thus means the equal use of freedom for all.

4. Deduction: The doctrinal legal justification of the various legal doctrines where the right of self-determination is absent

\section{a) Obligation to contract and lack of self-determination}

The obligation to contract can be justified from private autonomy itself: At a first glance, the obligation to contract is opposed to freedom of contract because one side loses the freedom to conclude contracts referred to above ${ }^{65}$ However, that is only applicable when one only considers the opposing party to the contract, the party refusing to accept, in isolation. Freedom of contract, however, is a conditioned freedom which is aimed at fulfilling mutual interests. If freedom of contract includes the self-determined decision of both sides, then private autonomy also allows the freedom to

61 Moreover, it referred to the welfare state principle (Art. 20 (1), 28 (1) Sentence 1 GG), see BVerfGE 89, 214, 231 et seq. (fn. 60)-guarantee agreements.

62 Thomas M.J. Möllers, Juristische Methodenlehre, section 7, § 73 (2017).

63 Sections 1821, 1822 in conjunction with 1643 BGB; section 1901 (1) Sentence 2 BGB; section 2064 BGB.

64 Joachim Rückert, HKK-BGB, with section $1, \S 43$ et seq. (2003), who speaks of a principle of equal legal freedom; agreeing Sibylle Hofer, Vertragsfreiheit am Scheideweg, 11 (2006).

65 Werner Flume, Allgemeiner Teil des Bürgerlichen Rechts, vol. 2, 611 (4 $4^{\text {th }}$ ed. 1992); Jörg Neuner, Privatrecht und Sozialstaat 287 (1999): "because it hereby involves the opposite of self-determined legal consequences". 
form a contract and thus the right, under certain conditions, to force conclusion of a contract. Freedom of contract is impaired when there is no choice. ${ }^{66}$ The reliance on the service clarifies the lack of self-determination, when there is an obligation to contract. ${ }^{67}$ The self-determination of the party wishing to contract is severely restricted in the absence of alternatives, such that the self-determination of the other party is, by way of exception, restricted. The obligation to conclude a contract in this respect establishes a legal obligation which includes the obligation to give a declaration of intent aimed at the conclusion of a contract. ${ }^{68}$

b) Price controls under section 138 para. 1 BGB for contracts which intervene in the self-determined life with severe freedom-restricting consequences

Formally, the judgments on price controls for contracts ${ }^{69}$ are not particularly convincing because the presumption of a reprehensible attitude in the event of a disparity between benefit and consideration only constitutes an apparent justification ${ }^{70}$ and fiction ${ }^{71}$. In terms of content, such judgments are to be rejected because they contradict the BGB. The wording of section 138 para. 2 BGB also requires, with the need for a conspicuous disparity, exploitation of plight and therefore does not directly provide any general

66 Thus Josef Kohler, Lehrbuch der Rechtsphilosophie, 96 (1909); Jan Busche, Privatautonomie und Kontrahierungszwang, 125 et seq. (1999), in addition to the legally protected interests, mentions the dependence on the provider.

67 Lorenz Fastrich speaks of "existential dependence", Richterliche Inhaltskontrolle im Privatrecht, 232 et seq. (1992). On dependence, see Walter SchmidtRimpler, 147 AcP 130, 157 fn. 34 (1941).

68 Christian Armbrüster, BGB, with section 145 paragraph 31 (Walter Erman ed., $14^{\text {th }}$ ed. 2014).

69 BGH, November 26, 1997, VIII ZR 322/96, BB 1998, 393 - slot machine; BGH, November 10, 2016, IX ZR 119/14, ZIP 2017, 2479 recital 19 et seq. - immorality of a fee agreement, furthers comments Volker Römermann, EWiR 2017, 45 et seq. who criticises why exactly the quintuple shall justify immorality; BGH, July 10, 1986, III ZR 135/85, BGHZ 98, 174, 178; BGH, January 19, 2001, V ZR 437/99, BGHZ 146, 298, 302.

70 Helmut Koziol, 188 AcP 183, 207 (1988).

71 Theo Mayer-Maly, Das Bewußtsein der Sittenwidrigkeit, 12 (1971); Theo Mayer-Maly, Festschrift for Röhricht, 395, 400, 404 et seq. (1983); Werner Ebke, Festschrift for Westermann, 183, 193 (2008). 
price controls. It is thereby fundamentally left to the contracting parties to determine the content and extent of the essential components of the contract (essentialia negotii) and to specify the price. Moreover, it would be systematically inconsistent if an unlawful threat or a fraudulent deception were "only" to lead to a right to void, but a particularly large disparity in benefit would lead ipso iure to invalidity under section 138 BGB..$^{72}$ Furthermore, it would be counterproductive if anyone were to be able to rely on judicial price control: The consequence would be a multitude of imprudent contracts being concluded. ${ }^{73}$

According to the view represented here, simple contracts of sale or contracts of service are not subject to the immorality and price control of section 138 BGB. ${ }^{74}$ Instead of employing an immorality review of the relevant market, however, the breach of a duty to inform ${ }^{75}$ or fault in conclusion of the contract (culpa in contrahendo) can intervene in such a case. ${ }^{76}$ The BGH therefore correctly rejected immorality when a purchaser had acquired collectors' coins at a price of DM 20,000, and could then only resell them for the value of the metal at DM $2,250 .^{77}$ The market, and not the judge, thus fundamentally determines the reasonableness of the price.

Situations of imbalance can only be relevant when the consequences are exceptionally onerous and the self-determination is therefore massively impaired. ${ }^{78}$ Contracts restrict the self-determined life when they act to severely

72 Rainald Maaß, NJW 3467, 3468 (2001); Thomas Fikenauer, Festschrift for Westermann 183, 205 (2008).

73 Horst Bartholomeyczik, 166 AcP 30, 62 (1966).

74 Also opposed, Theo Mayer-Maly, Festschrift for Larenz, 395, 398 et seq. (1983), Thomas Fikenauer, Festschrift for Westermann, 183 et seq. (2008), Joachim Rückert, HKK-BGB, with section $1 \S 112$ (2003).

75 Thus Reinhard Singer, JZ 195, 197 (2001) against the opinion of the BGH collector's coin (fn. 77).

76 BGH, December 22, 1999, VIII ZR 111/99, NJW 2000, 1254, 1255 - collector's coin.

77 BGH, December 22, 1999, VIII ZR 111/99, NJW 2000, 1254, 1255 - collector's coin. The hire purchase of pool/billiards equipment at 2.5 times the value was also not immoral, BGH, January 24, 1979, VIII ZR 16/78, WM 1979, 491, 492. See also above, III.2.b).

78 BVerfG, October 19, 1993, 1 BvR 567, 1044/89, BVerfGE 89, 214, 232 - Guarantee contract; Ritgen, JZ, 114, 119 (2002); Sibylle Hofer, Vertragsfreiheit am Scheideweg, 23 (2006); Josef Drexl, Die wirtschaftliche Selbstbestimmung des Verbrauchers, 208, 296 (1998); Claus-Wilhelm Canaris, Festschrift for Lerche, 
restrict freedom. It is not justice, but rather injustice which is the standard for a legal intervention. The exploitation of a position of power or the restriction of freedom are also recognised as grounds for attribution within the general clause in section 138 BGB. After conclusion of the contact, one can include cases of loss of perspective ${ }^{79}$ or the restriction of freedom in existential areas of life. ${ }^{80}$ The case law here has already developed groups of cases. For transactions of existential importance, exceptionally, there is price control. In German Law, this is relevant for rent, the purchase of property, or wages. ${ }^{81}$ Self-determination thus does not only refer to the exercise of a declaration of intent, but rather also the self-determined life, which should ensure that the wage is generally sufficient to live on, that tenancy law protects the tenant's social environment, and the purchase of a immorally inflated property does not drive the purchaser into the modern debtors' prison $^{82}$.

c) A freedom-restricting lack of equivalence as frustration of the contract

Also the legal doctrine of the frustration of contract is a weakening of the binding effect of the contract, that is, the principle of pacta sunt servanda. The doctrine of clausula rebus sic stantibus means that every contract is only binding for as long as the circumstances that were decisive for its signing have not changed fundamentally. ${ }^{83}$ The requirements and groups of

873, 883 et seq. (1993); Manfred Wolf and Jörg Neuner, Allgemeiner Teil des Bürgerlichen Rechts, $\S 10$ recital 30 ( $11^{\text {th }}$ ed. 2016).

79 For a different view, however, Manfred Wolf and Jörg Neuner, Allgemeiner Teil des Bürgerlichen Rechts, section $10, \S 55$ et seq. ( $11^{\text {th }}$ ed. 2016$)$, which understands this as "immaterial property rights of the social principle".

80 Wolfgang Enderlein, Rechtspaternalismus und Vertragsrecht, 293 et seq. (1996).

81 Similar examples in Manfred Wolf and Jörg Neuner, Allgemeiner Teil des Bürgerlichen Rechts, section 46, $\S 52\left(11^{\text {th }}\right.$ ed. 2016).

82 A debtors' prison was a private prison until the late Middle Ages and then a public prison for people who had not fulfilled their payment obligations, Steffen Breßler, Schuldknechtschaft und Schuldturm, 88, 115 et seq. (2004).

83 It can already be found in the Codex Maximilianeus bavaricus civilis [CMBC] and in the General State Laws for the Prussian States [ALR] and also in other codes, $4^{\text {th }}$ part, chapter $15, \S 12 \mathrm{CMBC}$ : "and because [...] all connections tacitly contain the clausulam sic stantibus"; $1^{\text {st }}$ part, $5^{\text {th }}$ title, sections $377-380$ ALR; as 
cases of frustration of contract were developed inductively within 80 years. Two key features are crucial: The background is, on the one hand, again the observation that courts cannot and should not review equivalence with frustration of contract. On the other hand, only in extreme circumstances, namely, situations which were not discernible for the contracting parties on conclusion of the contract and which massively disrupt the balance of the contract, an adjustment to the contract can be made. ${ }^{84}$ Justice is thus specified as a legal concept through the principle of self-determination. This specifies the prerequisites of frustration of contract. The disruption may not fall within one of the contracting parties' areas of risk. In the event of a disruption of equivalence, it requires that the sphere of freedom is existentially impaired. It concerns cases which are simply incompatible with law and justice. ${ }^{85}$ The disruptions of equivalence must therefore clearly be more than $50 \%$ of the market price ${ }^{86}$ and again have severely restrictive impacts on freedom.

\section{Lex superior - Primacy of Law}

\section{The legal situation in Germany}

a) The principle lex superior

In the 1930 s, Merkl invented the hierarchy of the law ${ }^{87}$ which stipulates that the legal system is built on different levels of legal provisions that are

well Art. 357 Polish Civil Code. In detail see Thomas M.J. Möllers, Juristische Methodenlehre, $\$ 11$ recital 37 (2017).

84 Bundestag document no. 14/6040, 176: "gross disparity with the creditor's interest in performance"; Claus-Wilhelm Canaris, JZ 499, 502 (2001). See BGH, February 25, 1993, VII 24/92, BGHZ 121, 378, $392 \S 54$ : "when it concerns such a drastic change that adherence to the original provision would lead to an intolerable outcome which can plainly no longer be reconciled with law and justice, and adherence to the original contractual provision would therefore be unreasonable for the affected party". Similarly Marc-Philippe Weller, Die Vertragstreue, 298 et seq (2009).

85 Thus the formulation in Horst Eidenmüller, Jura 824, 829 (2001).

86 Devaluation by more than $60 \%$, see BGH, September 18, 1992, V 116/91, BGHZ 119, 220, 222 - increase in the ground rent; on this group of cases see Hein Kötz, Vertragsrecht section 1014 et seq. ( $2^{\text {nd }}$ ed. 2012).

87 Adolf Julius Merkl, Festschrift for Kelsen, 252, 272 et seqq (1931). 
ranked in a super- and subordinate relationship. Insofar there is a hierarchy of provisions. The higher level is the reason for existence of the respective lower level and regulates the procedure as to how the lower provision comes into existence and, if needed, also its content. The doctrine of the hierarchy of the law has become prevailing. ${ }^{88}$ The legal consequences of the hierarchical structure are considerable. If two provisions that are per se valid, but are derived from different sources and regulate the same legal question, create a direct contradiction, then this gives rise to a collision of provisions. ${ }^{89}$ A collision arises when two different legal provisions regulate the same legal problem. If provisions collide, there is no balancing of the individual provisions. On the contrary, one rather applies an unambiguous priority rule. The higher-ranking law takes precedence over the lower-ranking law, Latin: lex superior derogat legi inferiori. ${ }^{90}$ In modern times, this concept developed from the observation that the higher-ranking legislator is able to impede or abolish a contradicting law of the lower-ranking legislator. ${ }^{91}$

\section{b) Higher rank of rules on competences}

Germany is a federal constitutional state. According to the federal law the state law needs to be respected. Art. $31 \mathrm{GG}$ is succinctly phrased: "Federal law precedes state law". Art. 31 GG derives from the states' self-conception

88 Hans Kelsen, Reine Rechtslehre, 228 et seqq. (2 ${ }^{\text {nd }}$ ed. 1960); Klaus F Röhl and Hans Christian Röhl, Allgemeine Rechtslehre, 308 et seq. ( $3^{\text {rd }}$ ed. 2008); Bernd Rüthers, Christian Fischer and Axel Birk, Rechtstheorie, recital 272 et seqq. ( $9^{\text {th }}$ ed. 2016); Franz Bydlinski, Juristische Methodenlehre und Rechtsbegriff, $201\left(^{\text {nd }}\right.$ ed. 1991); Ernst A. Kramer, Juristische Methodenlehre, 96 ( $5^{\text {th }}$ ed. 2016); differing view for example Gunther Teubner, 2 Soziale Systeme, 229, 231 (1996): ,terrific self-deception of the law“.

89 BVerfG, June 4, 1969, 2 BvR 173/66 among others, BVerfGE 26, 116, 135; Klaus Stern, Das Staatsrecht der Bundesrepublik Deutschland, vol. 1, 720 (2. ed. 1984).

90 In the words of Adolf Julius Merkl, Festschrift for Kelsen, 252, 276 (1931): "A legal rule derogating another legal rule, while this other legal rule does not equally derogate it, is for this reason higher-ranking and the legal rule that is derogated is lower-ranking compared to the legal rule that derogates."

91 Lex superior tollat legem inferioris, see Sebastiano Medici, De legibus, statutis, et consuetudine, 90 (Sebastiano Medici et al. eds., 1574); see also Jan Schröder, Recht als Wissenschaft, 21 ( $2^{\text {nd }}$ ed. 2012). 
and is a classical lex superior principle. ${ }^{92}$ Comparable rules can be found in Switzerland, Australia, Canada and indirectly also in the US Constitution. ${ }^{93}$ Subsequently, the entire federal law precedes the entire state law. It would therefore generally be possible that a provision of the state constitution was considered void because it is inconsistent with an ordinance of the federal government. Art. $31 \mathrm{GG}$ is, however, mostly superseded by more specific provisions, as for example the legislative power of sections 70 et seqq. GG. ${ }^{94}$

This conflict can also arise between the EU and the member states. Under certain conditions European law precedes the national law, which is called primacy of application. The result is that national law may not be applied. ${ }^{95}$

\section{c) Primacy of the Constitution}

A subsequent result is that ordinary law must be interpreted in light of the constitution because it is higher-ranking than ordinary law. The constitution-oriented and constitutional interpretation must be distinguished from the constitutional development of the law. ${ }^{96}$

\section{The Primacy of Law in Chinese Law}

a) The Primacy of Law according to Art. 95 Legislation Law

In Chinese law the principle of primacy is also known: it is codified in Art. 95 Legislation Law which is worded: ${ }^{97}$

92 It is insofar referred to ranking norms, see Peter M. Huber, GG, Art. 31 recital 7 (Michael Sachs and Peter M Huber eds., $7^{\text {th }}$ ed. 2014); differing view Horst Dreier, GG, Art. 31 recital 18. (Horst Dreier ed., $3^{\text {rd }}$ ed. 2015),

93 S. U.S. Const. art. 1, sec. 1; art 1, sec. 8 para. 18 ; art. 6 para. 2; U.S. Const. amend. X; Winfried Brugger, Einführung in das öffentliche Recht der USA, 31 et seqq. ( $2^{\text {nd }}$ ed. 2001).

94 Besides Art. 70 et seqq., 84 para. 1 p. 4, 125a para. 1 p. 2 and Art. 142 GG; Peter M. Huber, GG, Art. 31 recital 5 ff. (Michael Sachs and Peter M. Huber eds., $7^{\text {th }}$ ed. 2014).

95 Thomas M.J. Möllers, Juristische Methodenlehre, $\S 8$ recital 4 et seqq. (2017).

96 Thomas M.J. Möllers, Juristische Methodenlehre, $\$ 7$ recital 37 et seqq. (2017); Thomas M.J. Möllers, Festschrift for Vedder, 721 et seqq. (2017).

97 This reference is owed to Jin Jing. 
"When local provisions and rules are inconsistent, the relevant organ will make a ruling in accordance with the following provisions on the scope of authority:

(1) When a new general provision and an old special provision enacted by the same agency are inconsistent, the enacting agency shall make the ruling;

(2) When local provisions and administrative rules are inconsistent regarding the same matter and the applicable provision cannot be determined, the State Council will issue an opinion and where the State Council finds that the local decree shall apply, the local decree shall be applied in the local jurisdiction; where the State Council deems that the administrative rule shall apply it shall request the Standing Committee of National People's Congress to make a ruling;

(3) When there is an inconsistency on a matter between departmental rules or between departmental rules and local provisions the State Council will make a decision. When an administrative regulation enacted pursuant to authorization and a law are inconsistent and the applicable provision cannot be determined the Standing Committee of National People's Congress will make a ruling."

As well as in Germany, Europe and the USA it is recognised that the competences of different governmental authorities can conflict with each other, which can be solved by means of the hierarchy of norms.

b) Chinese Law and the Constitution, section 1 GRCL

In China, however, the question as to how to interpret the constitution has not been solved yet. For instance, it is hardly clarified if only the Standing Committee of the National People's Congress or the courts are allowed to interpret the constitution. ${ }^{98}$ Also the question whether there is a hierarchy of several legal sources hardly seems to be clarified. ${ }^{99}$ It is also not clear whether there is a constitutional interpretation in Chinese law. ${ }^{100}$ The basic rights of the constitution are mainly perceived as mere agenda that are not legally binding and subsequently not enforceable either. ${ }^{101}$

98 For an overview see Hui Huang, Juristische Methodenlehre in China und Ostasien, 131, 152 (Yuanshi Bu ed. 2016).

99 To this Zhang, 1 Univ. Bologna L. Rev. 106, 117 (2016).

100 Sheng Zhang, China L.Science 110 et seqq. (2008); Hui Huang, Juristische Methodenlehre in China und Ostasien, 131, 152 (Yuanshi Bu ed. 2016).

101 One court dismissed a case regarding a fundamental rights violation, see Qi Yuling v. Chen Xiaoqi et al.: Dispute over Infringement of a Citizen's Basic Right to receive Education protected by Constitution Through Infringement of Right of Name, Supreme People's Court Gazette, 2001, Issue 5, 158-161 (齐玉 苓诉陈晓琪等以侵犯姓名权的手段侵犯宪法保护的公民受教育的基本 权利纠纷案 《最高人民法院公报》2001年第5期, 第158-161页). 
If the constitution is understood as a legal system that describes the tasks of the People's Party is it clear that now basic rights must be searched for in another codification, namely the GRCL. In the current version of the GRCL, the basic rights cannot only be perceived as legal assets that private third parties may not harm. They can be perceived as basic rights that the government has to respect. This is suggested by the fact that no one may harm them, section $3 \mathrm{GRCL}$. A wording that the absolute legal assets may not be harmed is doubtful. Examining basic rights it is recognised that the infringement of a basic rights is legal if it can be justified. Basic rights are always limited by the basic rights of third parties. The claim to absoluteness is therefore excessive.

A second remarkable particularity is: in German law the constitution and therefore the basic rights are higher-ranking than the ordinary civil law. However, basic rights are directly applicable. In relation to Public Law and Criminal Law a certain priority is given to Civil Law. Among several claims the civil claim to damages is preceding, sections 187 GRCL. The relation of basic rights and ordinary law should therefore not be examined as a relation of constitution and private law, but within the GRCL.

\section{$V$. Resolution of conflicts between principles through balancing - working} with basic laws

\section{No general principle of proportionality in the German BGB}

a) Affirmation of a principle of proportionality in Civil Law

It is heavily debated if a principle of proportionality exists in Civil Law. The BGH states that the principle of proportionality "governs the entire Civil Law" 102 and the German Federal Labour Court (Bundesarbeitsgericht - BAG) even calls it a "superordinate legal principle of the private law." 103

102 BGH, February 11, 1987, IVa ZR 194/85, BGHZ 100, 60, 64 - section 71 VVG; see also BGH, December 6, 1989, IVa ZR 249/88, BGHZ 109, 306, 312-grave violation of piety.

103 BAG, June 6, 1980, 1 AZR 822/79, BAGE 33, 140 recital 110 - Labor Dispute Law. 
Also a part of legal literature affirms the validity of the principle of proportionality for the Civil Law. ${ }^{104}$ As the legislative branch is also bound by the constitutional order according to Art. 1 para. 3 GG under Civil Law, the principle of proportionality applies. ${ }^{105}$ This shall also be valid for the jurisdiction of Civil Law. ${ }^{106}$ Methodologically, the principle of proportionality is tried to be derived from section $242 .{ }^{107}$ According to Canaris, under current law, a young person should not be obligated to pay the extremely high damages resulting from the destruction of an important artwork because such a claim violates the freedom of action and the prohibition of excessiveness, which also applies in Civil Law. ${ }^{108}$

b) Rejection of the principle of proportionality in Civil Law

The opposing view, however, criticises a general application of the principle of proportionality. ${ }^{109}$ It emphasizes the autonomy of Civil Law: First,

104 Hans Hanau, Der Grundsatz der Verhältnismäßigkeit, 121 et seq. (2004), Michael Stürner, Der Grundsatz der Verhältnismäßigkeit im Schuldvertragsrecht, 442 (2010); Claudia Schubert, Münchener Kommentar BGB, section 242 recital 417 et seqq. ( $7^{\text {th }}$ ed. 2016); Reiner Schulze, BGB, section 242 recital 33 (Reiner Schulze et al. eds., $9^{\text {th }}$ ed. 2017), on abuse of rights respectively; Jörg Neuner, NJW 2000, 1822, 1824 for the non-transactional sector; for Public Law: Helmuth Schulze-Fielitz, GG Art. 20 (constitutional state) recital 197 (Horst Dreier ed., $3^{\text {rd }}$ ed. 2015).

105 Manfred Wolf and Jörg Neuner, Allgemeiner Teil des Bürgerlichen Rechts, § 2 recital 2 (11 $1^{\text {th }}$ ed. 2016).

106 Claus-Wilhelm Canaris, JuS 161, 162 (1989).

107 Helmut Köhler, GRUR 82 (1996); Dirk Looschelders and Dirk Olzen, BGB, section 242 recital 277 et seqq. (Staudinger ed., revised ed. 2015).

108 Claus-Wilhelm Canaris, JZ 993, 1001 et seq. (1987); Claus-Wilhelm Canaris, JZ 494, 497 (1988).

109 Dieter Medicus, 192 AcP 35, 69 et seq. (1992); Detlef Merten, Festschrift for Schambeck, 349, 364 et seq. (1994); Christian Grüneberg, BGB, section 242 recital 54 (Otto Palandt ed., $77^{\text {th }}$ ed. 2018); Marcus Bieder, Das ungeschriebene Verhältnismäßigkeitsprinzip als Schranke privater Rechtsausübung, 27 et seqq. (2007); Lorenz Kähler, Verhältnismäßigkeit, 210, 212 et seqq. (Matthias Jestaedt and Oliver Lepsius eds., 2015); For Public Law: Detlef Merten, HGR, vol. 3 , § 68 recital 22 (2009). 
according to this view, the legislator has already perfectly balanced the interests. ${ }^{110}$ Second, the principle of proportionality would only be efficient to avert a public interference, but it would not be suitable among private persons because both parties could claim their basic rights. ${ }^{111}$ Therefore, the principle of proportionality is not applicable or only strictly limited: As an expression of self-determination the parties can generally generate contracts at will. The objective principle of equivalence does not apply. The BGB deliberately decided against a price control, the "laesio enormis" is only applicable in rare cases. ${ }^{112}$ Under Property Law the owner can make alterations at his or her will. ${ }^{113}$ The owner may destroy the property without being prohibited from doing so. ${ }^{114}$ Due to testamentary freedom the spouse or relatives can be excluded from the inheritance; only the claim to the legal portion of an estate is protected.

\section{c) Own opinion}

It can be agreed to the indirect effect of the basic rights under Civil Law, and that under Civil Law, the legislator is bound by the basic rights and therefore by the prohibition of excessiveness. This, however, does not result in the direct application of the basic rights under Civil Law. ${ }^{115}$ Moreover, the just mentioned provisions are not eligible for generalisation ${ }^{116}$ as they

110 Dieter Medicus, 192 AcP 35, 37 (1992); Ulrich Preis, Festschrift for Dietrich 429, 433 (1999).

111 Dieter Medicus, 192 AcP 35, 59 (1992); Ulrich Preis, Festschrift for Dietrich 429, 435, 438 (1999).

112 Also Thomas Raiser, Festschrift Deutscher Juristentag, vol. 1, 101, 129 et seqq. (1960); Franz Wieacker, Zur rechtstheoretischen Präzisierung des § 242 BGB, 38 (1956); Detlef Merten, HGR, vol. 3, § 68 recital 22 (2009); Lorenz Kähler, Verhältnismäßigkeit, 210, 225 (Matthias Jestaedt and Oliver Lepsius eds., 2015). Differing section 56 para. 1 sentence 2 VwVfG: "The consideration must be reasonable under the entire circumstances and materially connected to the contractual performance of the authority." See above III.2.b).

113 This principle has been carried on for hundreds of years.

114 Lorenz Kähler, Verhältnismäßigkeit, 210, 227 (Matthias Jestaedt and Oliver Lepsius eds., 2015).

115 Günter Dürig, Festschrift for Nawiasky 157, 176 et seqq. (1956); BVerfG, January $15,1958,1 B v R 400 / 51$, BVerfGE $7,198,206$ et seq.

116 Detlef Merten, HGR, vol. 3, § 68 recital 22 (2009); Lorenz Kähler, Verhältnismäßigkeit 210, 217 et seqq. (Matthias Jestaedt and Oliver Lepsius eds., 2015). 
only relate to the defence of rights or the extent of enforcement. The reference to section 242 BGB is not convincing either, because this provision under the tradition of the Roman legal bonas fides ${ }^{117}$ only aims at certain obligations within a creditor-debtor relation without forcing a balancing of all the interests affected. ${ }^{118}$ Randomly correcting legal provisions with the principle of proportionality exceed the limits of permissible development of the law: The "art vandal", who intentionally destroys a valuable painting, is liable because the ownership of the injured person is clear. Moreover, the culprit is adequately protected by Bankruptcy Law. ${ }^{119}$

Establishing a balance of interests is incumbent upon the legislator. ${ }^{120}$ The legislator can clearly establish a better balance of interests than an examination of the proportionality by the courts. ${ }^{121}$ The examination of proportionality and its criteria of suitability, necessity and proportionality in the narrow sense would restrict the private autonomy in a manner contrary to the system. ${ }^{122}$ Opposing interests are imminent to synallagmatic contracts as for instance the purchase and service contract: One party wants to buy low, the other party wants to sell high. The judge is generally not interested in whether the bottle of Coca Cola is sold for 50 Cents or 5 Euros. Therefore, the individual generally does not have to act respecting any fiduciary duties or in the best interests of the other party, but may pursue only his or her own interests. Thus, Civil Law allows a right to excessiveness within the boundaries of section 138 and section 242 BGB and does not

117 Martin Joseph Schermaier, Good Faith in European Contract Law 63, 66 (Reinhard Zimmermann and Simon Whittacker eds., 2000).

118 Lorenz Kähler, Verhältnismäßigkeit, 210, 221 (Matthias Jestaedt and Oliver Lepsius eds., 2015).

119 Opposing Claus-Wilhelm Canaris, JZ 993, 1001 et seq. (1987); Claus-Wilhelm Canaris, JZ 494, 497 (1988); the following authors: Thilo Ramm, JZ 489, 491 et seq. (1988); Dieter Medicus, 192 AcP 35, 66 et seq. (1992); Ulrich Preis, Festschrift for Dietrich, 429, 460 (1999); Gerald Spindler, BGB, section 823 recital 0.12 (Heinz Georg Bamberger and Herbert Roth eds., $3^{\text {rd }}$ ed. 2012); Dirk Looschelders and Dirk Olzen, BGB, section 242 recital 278 (Julius von Staudinger ed., revised ed. 2015); Lorenz Kähler, Verhältnismäßigkeit, 210, 215 (Matthias Jestaedt and Oliver Lepsius eds., 2015).

120 Klaus Stern, Das Staatsrecht der Bundesrepublik Deutschland, vol. III/1, 1578 (Klaus Stern ed. 1988); Konrad Hesse, Grundzüge des Verfassungsrechts der Bundesrepublik Deutschland, recital $355\left(20^{\text {th }}\right.$ ed. 1999$)$.

121 Ulrich Preis, Festschrift for Dietrich, 429, 448 (1999).

122 Marcus Bieder, Das ungeschriebene Verhältnismäßigkeitsprinzip als Schranke privater Rechtsausübung 39 et seqq. (2007). 
perform a content review. In terms of a presumption rule, a refutable presumption for the validity of privately autonomous agreements applies. ${ }^{123}$

The legislator introduced the proportionality test when General Terms and Conditions and their one-sided shaping power impair the other party's self-determination: Clauses according to section 307 para. $1 \mathrm{BGB}$, for instance, are void if they "unreasonably disadvantage" the other party. ${ }^{124}$ Shaping powers, such as the termination of a contract, must be exercised proportionately. ${ }^{125}$ Here, the prohibition of the legally abusive exercise of a law under section 242 BGB is in effect.

The Constitutional Law, and thus also the proportionality control, must always be considered especially if the Constitutional Law directly affects the Civil Law. Decisions in the legal matters Lüth ${ }^{126}$ or Lebach ${ }^{127}$ illustrate that injunctive relief or damage claims under Civil Law must be limited. The general right of privacy, for example, must also be protected by the protection obligation of the State under Civil Law. However, this can be opposed by the freedom of opinion. Therefore, comprehensive balancing must be performed. ${ }^{128}$ The above-mentioned art vandal may, however, not claim that the liability for damages restricts his or her life planning in the long term if he or she caused the damage on the basis of self-determination. It would be absurd if the culprit who acted deliberately would not be held liable only because he or she caused particularly high damages. ${ }^{129}$

123 Ulrich Preis, Festschrift for Dietrich, 429, 440 (1999) and above III.3.b).

124 Ulrich Preis, Festschrift for Dietrich, 429, 440 (1999).

125 BGH, February 17, 1955, II ZR 316/53, BGHZ 16, 317, 322 et seqq. on section 140 HGB. Compare also section 133 para. 2 HGB.

126 BVerfG, January 15, 1958, 1 BvR 400/51, BVerfGE 7, 198 - Lüth.

127 BVerfG, June 5, 1973, 1 BvR 536/72, BVerfGE 35, 202 - Lebach.

128 BGH, October 26, 1951, I ZR 8/51, BGHZ 3, 270, 280 et seqq. - Constanze I; BGH, June 21, 1966, VI ZR 261/64, BGHZ 45, 296, 307 et seqq. - Hellfire; Gottfried Schiemann, HKK-BGB, sections 823, 830, 840, 842-853 recital 122 (2013); Hartwig Sprau, BGB, section 823 recital 95 et seqq. (Otto Palandt ed., 77 $7^{\text {th }}$ ed. 2018).

129 Differing view Claus-Wilhelm Canaris, JZ 993, 1001 et seq. (1987); Claus-Wilhelm Canaris, JZ 494, 497, fn. 108 (1988). 


\section{Principle of proportionality in Chinese Civil Law?}

The GRCL were not aware of the principle of proportionality; it was, however, at least debated in Public Law ${ }^{130}$. Ultimately, the principle of proportionality can only be transferred to Civil Law if the legislator establishes corresponding regulations as is the case in the dispositive Contract Law and the inspection of the General Terms and Conditions according to sections 309 et seqq. BGB. Apart from that, deducing a general principle of proportionality from section 6 GRCL must be handled with care. Instead, the freedom of contract must be properly determined. The obligations would have to be substantiated in detail through the Chinese Contract Law $^{131}$ as explained above.

\section{Summary}

1. The General Rules of Chinese Law (GRCL) of 2017 contain numerous legal principles of the General Part, as for instance legal transactions or the Law of Minors. Additionally, there are general legal principles such as the freedom to contract or the protection of absolute legal assets. Legal principles must be differentiated from the legal idea and the legal rule. Legal ideas such as justice, practicality, and legal security are highly abstract which renders them (useless) empty phrases in the resolution of cases. Legal rules or legal principles, however, can be subsumed.

The Civil Code, which was influenced by the Pandectics of the $19^{\text {th }}$ century ${ }^{132}$, trains the German jurist in systematic thinking, the legal dogmatics, and principles related thereto. For the development of

130 Yuanshi Bu, Einfuhrung in das Recht Chinas, 45 (2008) with further references.

131 See also Yuanshi Bu, Einführung in das Recht Chinas, 102 et seqq. (2008).

132 As for instance Anton Friedrich Justus Thibaut, System des Pandektenrechts, vol. 3, ( $5^{\text {th }}$ ed. 1846); Georg Friedrich Puchta, Pandekten ( $5^{\text {th }}$ ed. 1850$)$; Bernhard Windscheid, Lehrbuch des Pandektenrechts, vol. 3 ( $7^{\text {th }}$ ed. 1891); Heinrich Dernburg, Pandekten, vol. 3 (4 ${ }^{\text {th }}$ ed. 1894); Ferdinand Regelsberger, Pandekten, vol. 1 (1893); Reinhard Zimmermann, HKK-BGB, before section 1 recital 6 et seqq. (Matthias Schmoeckel et al. eds., 2003). 
law ${ }^{133}$, but also for a better understanding, consolidated legal dogmatics with legal principles are needed. ${ }^{134}$ Legal principles are not only non-binding ideas. Legal principles create meaning by means of their interaction and allow for a certain degree of generalisation. Legal principles generally claim normative validity and result in a presumption of conformity. They cannot be subsumed and need to be further substantiated.

2. In a first step, legal principles must be derived from the current law. In a second step, the rules must be substantiated. The legal sentence lex specialis derogat legi generali serves this purpose.

3. Further necessary substantiation has to be performed by balancing or induction and deduction. The aim is to establish legal rules as regulations with similar factual conditions.

In Civil Law, the freedom to contract is an important legal principle which can be derived indirectly from several provisions of the BGB. Individual legal rules, as for example, the obligation to contract, the price control, or the doctrine of frustration of contracts seem to contradict this principle. Neither an accuracy check, nor a social principle, nor the influence of the constitution are able to explain the obligation to contract, the price control, or the doctrine of frustration of contracts. These legal principles can rather be established by the principle of selfdetermination which is part of the private autonomy.

4. Further substantiation is possible through the principle lex superior derogat legi inferiori. This principle is for instance applicable to several governmental authorities as with regard to central power and province. It is, however, questionable, to what extent the basic rights of the constitution must be considered.

5. The collision of principles can also be used to substantiate principles. Balancing, which the principle of proportionality (section 6 GRCL) is based on, can be used for this purpose. However, balancing in German

133 On the function of general legal principles to fill gaps see above I.1.

134 Legal dogmatics is descriptively compared to grammar, without which the language, here the legal provisions, cannot be understood, Maximilian Herberger, Dogmatik, 37 et seq., 74 et seqq., 119, 257 et seqq. (1981) with detailed references on Roman law; Nils Jansen, ZEuP 750, 754 (2005). 
law is a domain of Public Law. Examining the basic rights, the sophisticated legal dogmatics, differentiates between scope of protection, infringement, justification, and exceptions for restrictions of basic rights. Details are, however, disputed because of the allocation of the burden of argumentation and justification: Using the fundamental freedoms generally does not require justification but attempting to restrict them does.

The principle of proportionality, however, is only restrictively applicable in Civil Law.

6. If the work with legal principles is correctly understood, principles can be directly derived from the valuations of the legislation and the law. Applying the customs according to section $10 \mathrm{GRCL}$ is therefore generally not necessary. 